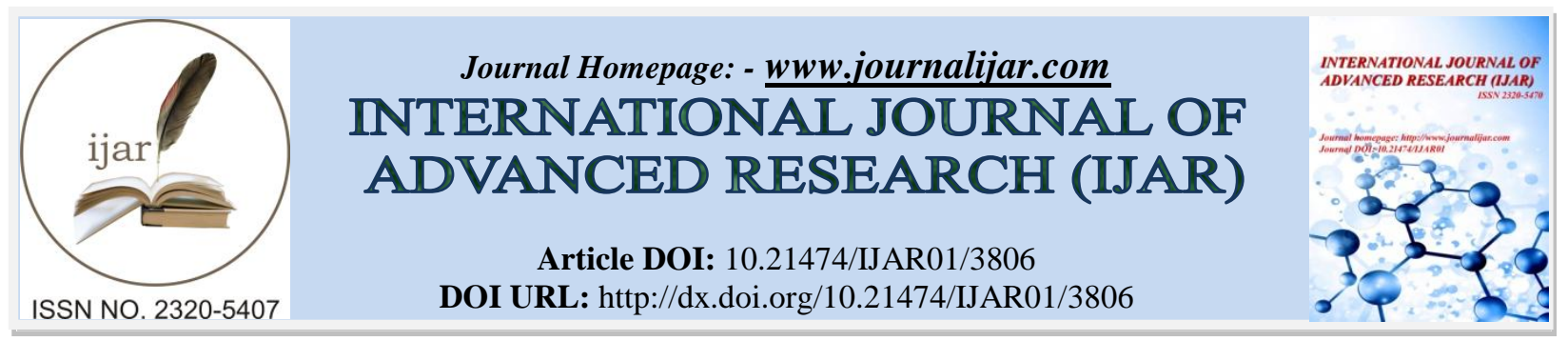

RESEARCH ARTICLE

\title{
A STUDY OF PERSONALITY CHARACTERISTIC OF CREATIVE STUDENTS IN RELATION TO COGINITIVE STYLE AND RISK- TAKING CHARCTERSTICS.
}

Dr. Mamta Bhardwaj.

Assistant Professor, Krishna Engineering College, Ghaziabad.

\section{Manuscript Info}

Manuscript History

Received: 01 February 2017

Final Accepted: 01 March 2017

Published: April 2017

Key words:-

Creative students, Cognitive style, Risk-

Taking, Personality

\section{Abstract}

In this study undertaken to examine the influence of personality characteristics of creative students of Cognitive Style and Risk-Taking of high school students, the investigator finds that there is no significant difference of personality characteristics of creative students and cognitive style while there is no significant difference between Personality Characteristic of creative students across risk-taking abilities.

Copy Right, IJAR, 2017,. All rights reserved.

\section{Introduction:-}

The cultural, scientific and social progress of any county depends upon the extent of the development of creativity among its citizens. Creative men and women are born in different social -economic and political circumstances. In the history of the world there had been several philosophers, poets, scientist, painters and writers who were turned out of their school classes but who created great work in their later life. Hence, in modern times the progressive nations try to develop creativity in their generations. The concept of creativity therefore, occupies a very important place in educational psychology.

Creativity is like height, weight and strength. People vary considerably in these dimensions but everybody has some height, some weight and some strength. Likewise there is a certain amount of creativity in all of us but some of us are obviously more creative than others. Creative students are generally characterized as self stimulating, independent, sensitive, goal oriented and capable of giving direction to their own efforts.

The creativity of a person depends on some personality traits. Certain traits like love of complexity, bold independent judgement, openness to stimuli, a strong motivation for pioneering and growth are as much conducive to creativity as freedom from block like fear of failure, allergy to ambiguity, conformity and rigidity etc. At the same time the creativity of a person depends upon certain abilities, specifically his convergent and divergent thinking and problem -solving skills.

Hence, an attempt would be made to distinguish creative adolescents from their less creative counter parts in terms of certain personality characteristics in conjunction with gender and socio-economic status.

\section{Statement Of The Study:-}

"A Study of Personality Characterstics of Creative Students in Relation to Gender and Risk-taking Status". 


\section{Objectives Of The Study:-}

$\mathbf{O}_{1}$. To identify the creative students.

$\mathbf{O}_{2}$. To study the personality characteristics of creative students.

$\mathbf{O}_{3}$. To study the personality characteristics of creative students across gender.

O. To study the personality characteristics of creative students across risk-taking status.

\section{Hypothses Of The Study:-}

$\mathbf{H}_{1}$. A significant number of creative students exist among population.

$\mathbf{H}_{2}$. There is no significant difference between personality characteristics of creative students.

H. There is no significant difference between personality characteristics across gender.

H. There is no significant difference between personality characteristics of creative students across risk-taking characterstics.

\section{Review Of Related Literature:-}

A lot of studies have been conducted with regard to creativity and personality characteristics but attempts made with regard to creativity and risk-taking characterstics with personality traits are less. The review of related literature plays a vital role in the world of research.

In the present study the researchers reviewed the literature relating creativity with personality characteristics and risk-taking status. The detailed description has been presented in the second chapter of this study. In the present study researcher has reviewed the related literature from Year 1990 - Nov. 2007

\section{Research Method Of The Study:-}

The objectives of the present study were designed to the study the personality characteristics of creative students in relation to Gender and risk-taking status of High School Level.

Therefore to achieve the objectives Normative Survey Method was done.

\section{Population Of The Study:-}

The population for the purpose of this study has been defined as class IX-Xth students (Boys and Girls) studying in all the high schools of Ghaziabad city.

\section{Sample And Sampling Techinque:-}

The present study was carried out on a sample of 230 students selected through Purposive Stratified Random Sampling.

Tool Used In The Study:-

$>\quad$ Verbal test of creative thinking (VTCT) Baqer Mehdi

$>\quad$ Yashvir Singh Personality Inventory Yashvir Singh \& Harmohan Singh

$>\quad$ Risk-taking Inventry Jackson and jackson

\section{Statistical Techniques Used:-}

The following statistical techniques used for the present study to fulfill related hypotheses.

1. Percentage $(\%)$

2. Chi-square

\section{Interpretation Of Result:-}

The title of the present study was "A study of Personality Characteristics of Creative Students in Relation to Gender and Risk -taking status". To study aimed at achieving the following objectives.

$\mathbf{O}_{1}$. To identify the creative students

$\mathbf{H}_{1}$ : A significant Number of creative students exist among population.

\section{Procedure:-}

After administration of tool the data was collected and raw scores were converted into percentage. The students who gained 50 or above 50 percent were included in creative category . 
Table Showing The Percentage Of Creative Students Among Population

\begin{tabular}{|c|c|c|}
\hline Total No. of students & Students selected as creative & $\begin{array}{c}\text { Percentage of creative students among } \\
\text { population }\end{array}$ \\
\hline 230 & 120 & $51.74 \%$ \\
\hline
\end{tabular}

\section{Result:-}

The $51.74 \%$ of students were found creative among the population

$\mathbf{O}_{2}$. $\quad$ To study the personality characteristics of creative students.

$\mathbf{H}_{2}$ : There is no significant difference between personality characteristics of creative students.

\section{Procedure:-}

After administration of tool the data was collected and raw scores were identified into introverts and extroverts

Table showing personality characteristics (Extrovert/ Introvert) in total creative students.

\begin{tabular}{|c|c|c|c|c|}
\hline $\begin{array}{c}\text { Total No. of } \\
\text { creative } \\
\text { students }\end{array}$ & $\begin{array}{c}\text { Total Number } \\
\text { of Extroverts }\end{array}$ & $\begin{array}{c}\text { Percentage of Extroverts } \\
\text { from creative students }\end{array}$ & $\begin{array}{c}\text { Total No. of } \\
\text { Introverts }\end{array}$ & $\begin{array}{c}\text { Percentage of introverts } \\
\text { from creative students }\end{array}$ \\
\hline 120 & 63 & $52.5 \%$ & 57 & $47.5 \%$ \\
\hline
\end{tabular}

\section{Result:-}

There are $47.5 \%$ introverts and $52.7 \%$ of extroverts were found in total 120 creative students.

$\mathbf{O}_{3}$ : $\quad$ To study the personality characteristics of creative students across gender.

$\mathbf{H}_{3}$ : There is no significant difference between personality characteristics of creative students across gender

\section{Procedure:-}

After administrating the tool the raw scroes identified the personality characteristics introverts and extroverts with relation to gender. The critical value $(3.84,6.635)$ is more than calculated value $(1.693)$ so the null hypothesis is accepted.

Contingency Table Showing Personality Characteristics Of Creative Students Across Gender.

\begin{tabular}{|l|c|c|c|c|c|}
\hline $\begin{array}{c}\text { Personality } \\
\text { Characteristics } \\
\text { Gender }\end{array}$ & Intro & Extro & Total & $\begin{array}{c}\text { Calculated } \\
\text { Value }\end{array}$ & Critical Value \\
\hline Male & 25 & 35 & 60 & & \\
\hline Female & 32 & 28 & 60 & $\mathbf{1 . 6 3 9}$ & $.05-3.81$ \\
\hline Total & 57 & $\mathbf{6 3}$ & 120 & & \\
\hline
\end{tabular}

Result:-

So the personality characteristics of creative students have no significant difference across gender.

$\mathbf{O}_{4}$ : $\quad$ To study the personality characteristics of creative students across risk-taking status.

$\mathbf{H}_{4}$ : There is no significant difference between personality characteristics of creative students across risk-taking status.

Procedure:-

The critical value $(3.84,6.635)$ is more than calculated value $(.991)$ so the null hypothesis is accepted.

Contingency Table Showing Personality Characteristics Of Creative Students Across Risk - Taking Status.

\begin{tabular}{|l|c|c|c|c|c|}
\hline $\begin{array}{c}\text { Socio Economic } \\
\text { Status }\end{array}$ & Intro & Extro & Total & Calculated Value & Critical Value \\
\hline High & 22 & 30 & 52 & & \\
\hline Low & 35 & 33 & 68 & .991 & 3.81 \\
\hline Total & 57 & 63 & 120 & & \\
\hline
\end{tabular}

Result:-

Therefore there is no significant difference in personality characteristics of creative students across risk-taking status. 


\section{Findings:-}

1. Being a Universal phenomena, creativity founds in every human being. In the present study $51.74 \%$ students were creative among population.

2. The extroverts were $52.5 \%$ and introverts in total population generally there is no significance difference of personality characteristics of creative students. Approximately similar ratio of introvert and extrovert was found in creative students.

3. There is no significance difference between personality characteristics of creative students across gender.

4. There is no significance difference between personality characteristics of creative students across rIsk-taking status.

\section{Educational Implications:-}

The present study has a lot of educational implications in the fast moving scientific era. Today everybody is more conscious towards education. One does not seem to be satisfied with achieving the lower aim. Rather one wants to get fame by doing something new and unusual. But this is possible only when one does have a lot of creative thinking and imagination.

Sometimes a person is not able to achieve the things that he wants, due to his low socio-economic status coming in his way. But if he is identified by the teachers, to be having high creativity, then he can be set in a then he can be indicated in a positive direction. So transformation or changes can be done with regard to the various areas of school environment so that students forget about their status and go ahead towards becoming more creative and proving to be useful human beings to the society in the coming days. Because the ultimate aim of education is to develop simultaneously all the aspects of the child together, by equalising them within the four walls of the school as well as in the society.

The results suggest that the educational methods and teaching styles of classroom instruction should vary so that creative students may optimally benefit from instruction. Creative students may be most productive when they derive their answer from an existing paradigm, receive specific assignments and support. Most of them work best when they are spontaneous and allowed to function independently.

\section{Refereces:-}

1. Gautam, Shashi Bala and Singh, Kulwinder (1992). An study of certain personality correlates of intellectual giftedness among navodaya vidyalaya students of Himachal Pradesh. Journal of Education and Psychology, 49(3-4), 40-44

2. Heiss, Rachel Harriet (1995). Personality and interests of gifted adolescents : Differences by gender and domain, Dissertation Abstracts International, 56 (5), 2922B.

3. Helode, R.D. 91986). Expressed characteristics of Creative Persons. Psycho-Lingua, 16(2), 107-117.

4. Helson, Revenna and Pals, Jennifer L. (2000). Creative Potential, Creative Achievement and Personal Growth. Journal of Personality, 68(1), 1-27.

5. Hjelle, Larry A. and Ziegler, Daniel J. 91985). Personality Theories : Basic Assumptions, Research and Applications. New York : McGraw Hill International.

6. Jalota, S. and Kapoor, S.D. (1975). Manual of directions and norms for Hindi and Punjabi versions of the eysenck's Maudsley Personality Inventory (EMPI) New Delhi : The Psycho-Centre.

7. Jalota, S. ; Pandey, R.N. ; Kapoor, S.D. and Singh, R.N. (1979). Manual for directions, Socio Economic Status Scale Questionnaire (SESSQ Urban). New Delhi : The Psycho-Centre.

8. Kundu, Dibakar (1987). Creativity and its relation to some personality variables in high school students - an empirical investigation, Journal of Psychological Researches, 31(2), 55-63.

9. McClileland, D.c. : Atkinson, J.W. ; Clark, R.A. and Lowell, E.L. (1953). "A Scoring Manual for the Achievement Motive." In Motives in Fantasy, Action and Society, by J.M. Atkinson, 1958, New Delhi : Affiliated East West Press Pvt. Ltd.

10. Singh, Kulwinder and Gautam, Shashi Bala (1988). A study of development of creative thinking among high school students of Himachal Pradesh in relation to residential background and economic status. Praachi Journal of Psycho- Cultural Dimensions, 4(2), 29-35.

11. Torrance, E. Paul (1969), Guiding Creative Talent, New Delhi : Prentice Hall of India Pvt. Ltd. 